\title{
Khao Sam Roi Yot - one of the world's most threatened parks
}

\author{
John W. K. Parr, Narong Mahannop and Vatid Charoensiri
}

Thailand has the best protected-area system in South East Asia, comprising 74 national parks and 34 wildlife sanctuaries. However, the integrity of these sites is far from assured: some are 'paper parks', which are being subjected to increasing human pressure. One site, Khao Sam Roi Yot National Park, has suffered some of the most extreme degradation.

\section{Introduction}

Khao Sam Roi Yot National Park is located 275 $\mathrm{km}$ south of Bangkok on the east coast of Prachuap Khiri Khan province on the Gulf of Thailand (Figure 1). It was established in 1966 as Thailand's third national park and its first marine park. It protects an outcrop of spectacular wooded limestone mountains rising to $605 \mathrm{~m}$, surrounded by paddy-fields, coastal marshes and degraded mangroves (Figure 1).

On 1 April 1982 the park was expanded westwards to protect the most important tract of reed-bed habitat in Thailand. The variety of habitats found in a relatively small area makes this site particularly valuable in conservation terms. The park is listed in A Directory of Asian Wetlands (Scott, 1989) as a site of international importance. According to the Royal Forest Department the area of the park is $98 \mathrm{sq} \mathrm{km}$, however, when the park area is measured from a map it appears to cover $162 \mathrm{sq} \mathrm{km}$.

\section{Fauna}

The steep limestone hills still support a population of mainland serow Capricornis sumatraensis, and leopard Panthera pardus and wild boar Sus scrofa still occur. The park also has populations of crab-eating macaque Macaca fascicularis and dusky leaf monkey Presbytis obscura - both with habituated groups that are easily observable - as well as the shy, nocturnal slow loris Nycticebus coucang. Other mammals present include common palm-civet
Paradoxurus hermaphroditus, banded linsang Prionodon linsang, Javan mongoose Herpestes javanicus, two species of otter, Malayan pangolin Manis javanica, Malayan porcupine Hystrix brachyura, fishing cat Felis viverrina, leopard cat $F$. bengalensis and Burmese hare Lepus peguensis.

The main freshwater marsh, covering 39.5 $\mathrm{sq} \mathrm{km}$, is of importance for many large waterbirds. It is only one of three known sites in Thailand where purple heron Ardea purpurea breeds, and there are scattered egret colonies. The site protects large populations of Chinese little bittern Ixobrychus sinensis, cinnamon bittern I. cinnamomeus, purple swamphen Porphyrio porphyrio, water rail Rallus aquaticus, ruddy-breasted crake Porzana fusca, whitebrowed rail $P$. cinerea and bronze-winged jacana Metopidius indicus, among others. Annual wintering or non-breeding visitors include grey heron Ardea cinerea (up to 117 birds), painted stork Mycteria leucocephala and oriental ibis Threskiornis melanocephalus. Over 7000 garganey Anas querquerdula are found in winter as are a few thousand Indian whistling duck Dendrocygna jazanica (pers. obs.).

The marsh supports a great variety of wintering migrant passerines and is probably of conservation importance as a site for wintering Acrocephalus spp. and other warblers. It is the only known wintering site for the rare and little known Acrocephalus agricola tangorum and may be the southernmost wintering area for bluethroat Erithacus svecicus (and possibly many other species) in continental South East Asia (Conservation Data Center, 1992). 


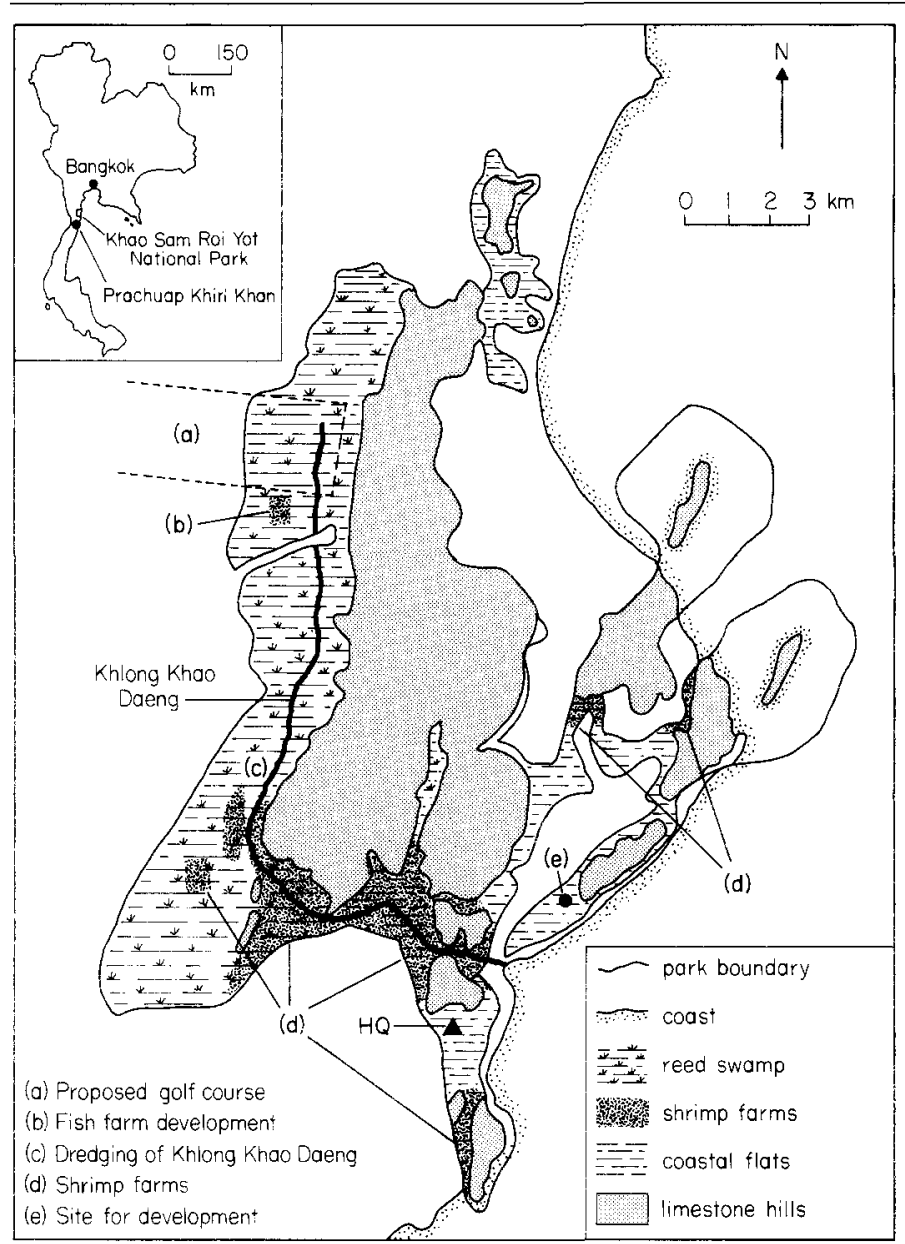

Figure 1. A map of Khao Sam Roi Yot National Park showing its location, habitats and encroachment.
The site is important for wintering raptors. In addition to many eastern marsh harriers Circus aeruginosus spilonotus and pied harriers C. melanoleucus, several greater spotted eagles Aquila clanga winter over the marsh.

Over 3000 wintering shorebirds of up to 48 species are at times present in the paddyfields, grazing marshes, mudflats and sandy beaches. In the paddy-fields are wood sandpiper Tringa glareola, marsh sandpiper T. stagnatilis, long-toed stint Calidris subminuta and black-winged stilt Himantopus himantopus. The mudflats support greenshank Tringa nebularia, redshank Tringa totanus, Terek sandpiper Xenus cinereus (over 80), broad-billed sandpiper Limicola falcinellus (up to 105) and several hundred rufous-necked stint Calidris ruficollis. Several endangered spotted greenshank
Tringa guttifer are recorded during the winter and up to 47 great knot Calidris tenuirostris are regular on passage (pers. obs.)

Several pairs of Malaysian sand plover Charadrius peronii and a colony of little terns Sterna albifrons, two species whose breeding success may be adversely affected by tourism, breed on the sandy beaches.

\section{A history of hostilities}

The park was set up in 1966 on $61.3 \mathrm{sq} \mathrm{km}$ of largely mountainous land. In December 1970 the Cabinet declared the $69.3 \mathrm{sq} \mathrm{km}$ marshland adjacent to the park would be set aside for land resettlement for villagers. The marsh flooded annually and the soil was acidic and 


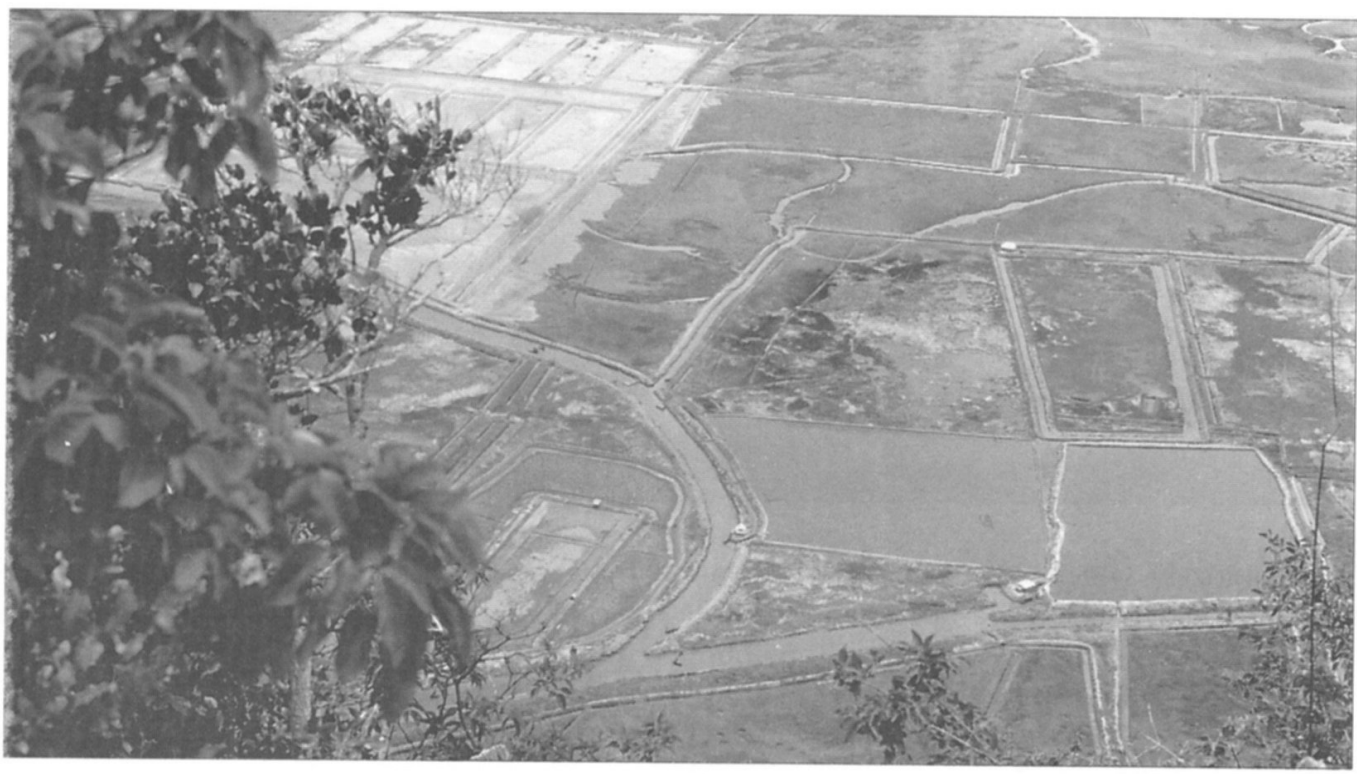

The influence of a few wealthy landlords as well as a number of local government officials, has resulted in a patchwork of illegal shrimp farms occupying most of the low-lying areas within the park. This photograph, taken from a hilltop, shows the freshwater marsh in the south-western part of the park.

unsuitable for farming. At the request of the National Committee on Wildlife and Natural Resources, $39.5 \mathrm{sq} \mathrm{km}$ of the marsh was annexed to the park area in 1982 and the rest was put under the responsibility of the province to provide farmland for the villagers.

Following the incorporation of the marsh within the park boundary a conflict arose between the superintendent and the local district authorities. It resulted in the local District Officer of Kuiburi (14 km south-west of the park headquarters) disseminating misinformation as to where the park boundary lay and infringement of the local villagers' rights. The villagers demonstrated against the park and tried in vain to burn down the headquarters.

The villagers petitioned the government to reduce the size of the park and redefine the boundary. In 1986 the government formed a committee of all interested parties in an attempt to reach a settlement. The resulting recommendation was to reduce the extent of the park by about $14 \mathrm{sq} \mathrm{km}$. This was based solely upon the judgement of the superintendent of the time; it would have removed some of the most intact habitat from the park, and took no account of the hydrology of the site. The recommendation, which lacked approval from local villagers who wished to degazette the entire marsh, never reached the Cabinet for approval.

The subsequent boom of the black tiger prawn Penaeus monodon farming industry, which was promoted by the government, made the park more vulnerable to encroachment. The financial benefits of aquacuitural development encouraged local people to transgress park laws, often with support from influential figures and the active protection of some locai police.

Ultimately, degradation of the park was the responsibility of the park superintendents and the emphasis they placed on law enforcement. Some were extremely courageous, others less so. The resulting fluctuating policies were reflected in intermittent periods of rapid encroachment.

In early 1990165 prawn farmers were operating illegally inside the park. Encroachment was not confined to the coastal margins but extended into the freshwater marsh. In late May 1990 the park superintendent confiscated 


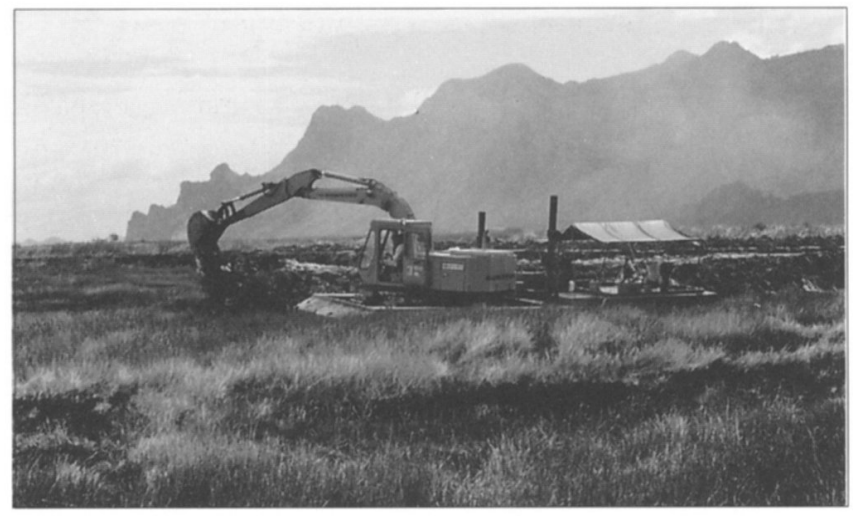

Weak law enforcement by individual park superintendents has contributed to the blatant conversion of the marshland habitat. six bulldozers, which belonged to a local businessman and which were operating illegally inside the park. However, this confrontation culminated in a visit by the then Deputy Minister of Agriculture, who lived close to the park and who was a friend of the businessman, flying in by helicopter to undermine the park's authority.

In November 1990, one of the highest ranking police officers in Thailand, who is a national figure regarding the prevention of illegal encroachment in protected areas, arrested 33 people who could not provide evidence of land-ownership documents. Another mob formed. The park superintendent received news from the Provincial Governor that his life was in danger and was offered 12 special police for protection. The superintendent, disillusioned with the lack of support from higher authorities in the Forest Department, retired from the National Parks Division.

The park was added to the list of most threatened parks in the world by the IUCN Commission on National Parks and Protected Areas (CNPPA) in spring 1991.

The situation became critical later in 1991 when the river Khao Daeng, the main outflow of the marsh, was illegally dredged by the local irrigation department. This accelerated drainage of the marsh and may have allowed the intrusion of saltwater. A count of illegal machinery in the park in June 1991 revealed 12 bulldozers and two cranes. A planned golf course by a former Member of Parliament in the northern part of the marsh also posed a threat. On the coast, a planned resort by a wealthy businessman also threatens the park's integrity (Figure 1).

The Police General was contacted about the encroachment and simultaneously the news was broken to the Thai press. Following threats from the Police General to take action should the Royal Forest Department fail to do so the Minister of Agriculture and other senior forestry officials visited the park on 26 July 1991. The Minister announced that the boundary of the park should be demarcated. He also ordered that there would be an inspection of land-ownership documents, whereupon illegal encroachers would be requested to leave within 3 months of his visit. Uncertain whether the government would abide by its promise and because the draining of the marsh was deemed severe, Thai non-governmental organizations requested international conservation organizations to petition the Prime Minister to safeguard the site.

The deadline passed without the government's promises being fulfilled. Letters of concern from virtually all appropriate international conservation organizations never reached the Prime Minister and were ignored by the authorities. The Thai conservation organizations could not co-ordinate a concerted front over the marsh, underestimating its conservation value. Bulldozers were reported to be operating within the park in early November 1991.

The letters of concern were presented to the National Parks Director in September 1992, which instigated a statement from the Deputy 
Minister of Agriculture in November 1992 demanding protective measures for the park. Regrettably, management of the park currently lacks direction and the degradation continues.

\section{Abuse of traditional resource utilization}

The freshwater marsh is 'common' land and its fisheries support an estimated 120 families living in, or immediately adjacent to, the marsh, as well as several hundred occasional users from further afield. Amphibians as well as fish are caught throughout the year; at night during the rainy season the marsh is scoured by dozens of locals with headlamps. The wetland also provides grazing land for cattle. These activities could continue to provide economic benefits without adversely affecting the resource base of the park.

These activities are being undermined by encroachment for aquaculture. Supported by a small number of wealthy landlords with surplus capital to invest, unprohibited, piecemeal encroachment into the marsh continues. Both the viability and sustainability of these shrimp ponds is questionable. The soil is highly acidic and has a high organic content, which, when exposed to air, encourages rapid bacterial growth which reduces oxygen levels in the ponds. Both factors decrease the economic viability of intensive aquaculture in the marsh. The freshwater marsh also plays an important role in supplying water to adjacent paddy-fields during the dry season and may well help to prevent the intrusion of saline water into agricultural land. This benefit may only become apparent if the reclamation of the freshwater marsh continues.

The prospects for the wetlands at Khao Sam Roi Yot National Park are currently bleak. Encroachment continues, community support for the park, where present, is suppressed by the activities of wealthy landlords and remains low and there is little political resolve to enable management to progress.

\section{Compilation of a management plan}

To help guide and control the management of the park, a management plan is needed that aims to integrate ecological management with the needs of the local people. Initially, the plan will require determination from senior forestry officials to combat encroachment, and the process will require the participation of representatives of local communities. The plan should clearly identify objectives and realistic goals. Commitment will then be required from all groups concerned to ensure that these goals are met.

\section{Acknowledgments}

The campaign to save Khao Sam Roi Yot National Park during the spring and summer of 1991 was funded by the Oriental Bird Club, to whom the author is deeply indebted. The authors wish to thank Mr Ross Hughes of the Asian Wetland Bureau, Kuala Lumpur and Janathan Eames of BirdLife International, for useful suggestions to the text. Further thanks to Dr Warren Brockelman and Mr Philip Round of the Center for Conservation Biology, Mahidol University, for comments on the drafts of the text.

\section{References}

Conservation Data Center. 1992. Checklist and Guide to Bird Finding. Birds of Khao Sam Roi Yot National Park. Mahidol University, Bangkok. 61 pp.

Land Use Classification Division. 1977-79. Land Use Maps of Thai Provinces Maps of Thai Provinces. Bangkok: Land Development Department.

Scott, D. (ed.) 1989. A Directory of Asian Wetlands. IUCN, Gland, Switzerland.

John W.K.Parr, Gatehouse Farm, Coldharbour Lane. Hildenborough, Tonbridge, Kent TN11 9LE, UK.

Narong Mahannop, Agriculture Extension and Cooperatives, Sukhothai Thammithirat Open University, Bangpood, Pakkred, Nonthaburi, Thailand.

Vatid Charoensiri, National Parks Division, Royal Forest Department, Phahon Yothin Road, Bangkhen, Bangkok 10900, Thailand. 